\title{
Sonority and Syllabic Structure in Reading: Difference Between French and English Readers
}

\section{N. Bedouin and P. Dissard}

\section{(2) OpenEdition}

1 Journals

\section{Electronic version}

URL: http://journals.openedition.org/cpl/207

DOI: $10.4000 / \mathrm{cpl} .207$

ISSN: $1379-6100$

\section{Publisher}

Centre PsyCLÉ

\section{Printed version}

Date of publication: 1 August 2002

\section{Electronic reference}

N. Bedouin and P. Dissard, « Sonority and Syllabic Structure in Reading: Difference Between French and English Readers », Current psychology letters [Online], 2002/2, 8 | 2002, Online since 05 September 2003, connection on 08 September 2020. URL : http://journals.openedition.org/cpl/207 ; DOI : https:// doi.org/10.4000/cpl.207

This text was automatically generated on 8 September 2020.

(C) All rights reserved 
Sonority and Syllabic Structure in Reading: Difference Between French and English Readers

N. Bedouin and P. Dissard 